\title{
A new system of government? \\ Defining the confidence relationship of the EU model
}

\author{
Diego Praino \\ (Oslo and Akershus University College of Applied Sciences / \\ ARENA Centre for European Studies, University of Oslo)
}

The Version of Record of this manuscript has been published and is available in Journal of European Integration, published online $01 \mathrm{Feb} 2017$, http://www.tandfonline.com, DOI: 10.1080/07036337.2017.1281264

\begin{abstract}
This paper attempts to define the EU system of government through an innovative approach that, taking into account both the legal framework and the political practice, focuses on the confidence relationship between the executive and legislative branches. This approach simplifies the comparative study of regime types, capturing the main distinctive features of systems that are neither presidential, nor parliamentary. The paper shows that the EU model does not belong to any of the traditional regime types; indeed, it represents a distinct system of government, characterized by a peculiar confidence scheme. Although the legal framework of the EU Treaties presents some elements of parliamentarism, the nature of the interinstitutional relations in the EU is not parliamentary; in particular, the role played by the European Council in the formation process of the Commission is not merely formal, and involves a much more complex confidence relationship.
\end{abstract}

\section{Keywords}

EU system of government; confidence relationship; regime types; parliamentarism

\section{Introduction}

The main aim of this contribution is to understand to what extent the EU system of government differs from more traditional regime types (especially parliamentarism), and to provide a consistent classification of the current EU model. This is achieved through a comparative analysis of the inter-institutional relations delineated by the EU Treaties with the traditional regime type categories. This inquiry is topical, considering the political and institutional dynamics that, under the new rules of the Treaty of Lisbon, led to the formation of the Juncker Commission, and the renewal of scholarly interest in this subject (see e.g. Fabbrini 2015). If 'typologies are no ends in themselves, but tools of scientific discovery' (Ganghof 2014, 656), then the classification of the EU model is a valid strategy to capture its main distinctive aspects and to better understand its development.

The paper focuses on the 'form' or 'system' of government, particularly on the structure of the relationship between the bodies that exert power (Bobbio 1995, 95). In other words, it takes into account the 'horizontal relations' (Fabbrini 2015, 572) among the main political 
institutions of the European Union. The paper argues that the EU does not belong to any of the 'traditional' regime types, but represents a distinct category based on a peculiar set of inter-institutional relations.

In order to provide a classification of the EU model, it is necessary to rethink which aspects should be taken into account in an inquiry on systems of government. Scholars do not agree on how to classify the current EU system, and the general categories suggested in the literature differ from each other and sometimes suffer from conceptual ambiguity (Elgie 1998). For this reason, this paper suggests an approach that is able to simplify the comparative study of regime types, capturing at the same time the main distinctive features of complex systems. The approach applied focuses on an analysis of the 'confidence relationship' between executives and legislatures; that is to say, of how the 'government's dependence on majority support in the legislature' (Huber 1996, 269) works in the several regime types.

The paper proceeds shedding some light on the scholarly debate on the nature of the EU model. This is followed by an examination of the concept of confidence relationship, and by an analysis of how the confidence relationship works in the European Union. Finally, a comparative analysis of the EU model against the traditional regime types is conducted in order to verify if the EU fits any of the general categories, or if it rather represents a distinct model.

\section{The difficult classification of regime types}

Scholars have compared the EU model both to parliamentarism and to presidentialism. Some have suggested that the institutional prerequisites for a parliamentary government in the European Union already exist (Hix 2008), and have argued that these features simply require political actors to behave as if they were in a parliamentary system. The focus of analysis has been on the emerging practice through which the European parties present, before the elections to the European Parliament (EP), candidates from their groups to compete for the role of President of the Commission. The idea behind this process is that, in voting for the legislature, EU citizens are able to 'politically' guide the appointment of the President of the Commission. This follows the tradition according to which the head of government is appointed by the head of state, who takes into account the result of parliamentary elections (Maduro 2013, 136). Weiler $(2013$, 750) has concluded that the transformation of the European Union into a parliamentary system of government 'can happen without any changes to the current treaties'. It has been suggested that even the involvement of the member states in the selection of commissioners (art. 17, para. 7, second subparagraph, TEU) could be 'neutralized' by a consistent political practice. It would be perfectly possible to establish the convention according to which all members of the Commission suggested by the national governments have to support the political program presented by the President of the Commission (Maduro 2013, 137). From this perspective, the EU does not differ much from a traditional parliamentary system, but it only lacks a consistent institutional practice.

Focusing on different distinctive elements, Fabbrini (2015) has questioned the parliamentary nature of the EU. In general, some authors see the main features of presidentialism in the complex inter-institutional relations that characterize the European model. For example, pointing out that the true political executive institution in the EU is the European Council, not the Commission, and that the members of the former 'are elected within their respective 
member states and are responsible to their domestic electorate', Kreppel $(2011,170)$ argued that 'the EU is unquestionably a separation of powers system'. Before the Treaty of Maastricht, Bogdanor $(1986,162)$ noted that the Community could only reach the goal of European Union by developing further the doctrine of separation of powers. Years later, arguing that the EU and the US 'converge towards a common model of compound democracy', Fabbrini $(2005,196)$ concluded that 'there are more similarities than there are differences between them', the first one being the institutional separation of the executive from the legislature.

Finally, other authors acknowledge the possibility of classifying the European Union as a distinct model. Decker and Sonnicksen $(2011,181)$ point out the 'difficulty of placing the EU clearly in one category', while Dann $(2003,573)$ wrote that the EU is neither parliamentary nor presidential, and can be defined as 'semi-parliamentary'.

The different interpretations of the EU model outlined above indicate that scholars study systems of government taking into account different variables. Indeed, the general categories provided are many and varied, especially when dealing with models that belong neither to presidentialism nor to parliamentarism. For example, while Lijphart (1984) has avoided considering semi-presidentialism as an autonomous model, Shugart and Carey (1992) have divided that category into two subtypes (premier-presidential and president-parliamentary). Elgie (1998) has explained that this conceptual ambiguity derives especially from the fact that most studies of regime types juxtapose dispositional and relational properties when classifying the empirical regimes. Therefore, he suggested simplifying the comparative study of forms of government, by focusing on dispositional properties alone.

However, even though authors have considered different variables in their analysis, there is one feature that has been widely accepted as a distinctive element between the two categories: the political accountability of the executive to the legislature (e.g. Lijphart 1999; Sartori 1994; Verney 1959). The main idea is that in parliamentarism 'the government's authority is completely dependent upon parliamentary confidence,' while in presidentialism the executive is 'independent' from the legislature's trust (Linz 1990, 52). Samuels and Shugart (2010) have broadly explored the connection between the two branches of government when studying models that differ from the two main regime types. They argue that the main question is to what extent the executive depends on the legislature as far as its origin and survival are concerned.

This paper examines the EU model through a comparative analysis of the 'confidence relationship' among the political institutions. The following section outlines why the idea of confidence is useful in the classification of regime types.

\section{The 'confidence relationship' as the distinctive feature of regime types}

The expression 'confidence relationship' describes the inter-institutional scheme according to which the executive and legislative branches of government are politically connected. This scheme derives from the combination of two different types of trust.

When the cabinet is politically accountable to the legislative body, the former needs a permanent confidence from the latter, that is to say, it requires parliamentary support for as long as it remains in office. The point is not so much that the executive can be removed, but that it can be removed by the legislature for a lack of political support, without special judicial 
procedures being activated. Impeachment mechanisms are different in this regard (Pizzorusso 1998, 207), since they cannot be used in the case of a lack of political support, but are connected to specific criminal behaviours and, for this reason, they might also involve the judiciary. For example, in the United States the President 'shall be removed from Office on Impeachment for, and Conviction of, Treason, Bribery, or other high Crimes and Misdemeanors' (art. II, sec. 4, US Constitution). The Chief Justice presides the trial in front of the Senate, and 'the Party convicted shall nevertheless be liable and subject to Indictment, Trial, Judgment and Punishment, according to Law' (art. I, sec. 3).

When the executive is appointed, elected, or implicitly accepted by the legislature, it means that it receives an initial confidence (cf. Luciani 2010, 548). Interpreting the investiture of a body as an expression of trust is consistent with the constitutional provisions of several systems. In Italy, for instance, 'the Government shall come before Parliament to obtain confidence' within ten days of its formation (art. 94, Italian Constitution). While in Spain, the King nominates for the Presidency of the Government a candidate who submits to the Congress the political programme of the Government he or she intends to form in order to seek the confidence of the House (sec. 99, Spanish Constitution).

These two types of trust are comparable as they both allow that the political dynamics within the legislative body affect the composition and the 'life' of the executive. What changes is that they operate in different moments: the initial confidence is expressed at the formation stage of the latter; the permanent confidence, instead, operates for as long as it remains in office. This paper starts from the premise that different combinations of these two types of trust (initial and permanent) determine different operational schemes, and each one of these schemes represent the main 'structure' of a distinct regime type.

This idea goes beyond the method of the analysis of the cabinet's origin and survival, and is useful for several reasons; in particular:

1) The concept of confidence simplifies the analysis and the classification of regime types, since it focuses only on those elements that are able to affect the 'structure' of the models. Either we describe the 'pure' models by means of long lists of features and then accept that the concrete experiences may deviate from those general archetypes, or we find a common 'core' or 'structure' shared by similar systems. In adopting the second approach, not every feature is relevant when studying regime types, precisely because only some contribute to delineate the confidence scheme (see Praino 2014). If the notion of system of government expresses 'the relationship between executives and legislatures' (Cheibub et al. 2014, 515), then the factors that must be taken into account are the relational properties that determine the nature of that relationship, and those factors can vary. For example, if on the one hand the list of presidential powers should be eliminated from the definition of semi-presidentialism (Elgie 2007, 4); on the other hand, the power to dismiss the Prime Minister becomes a decisive factor if it somehow alters the confidence relationship (as it happens e.g. in France). In short, the idea of confidence helps capture the essential elements that are able to alter the main structure of the model considered. Indeed, certain formal requirements (e.g. the type of majority needed in order to appoint or to vote down the executive) determine the manner in which the procedures work, but they do not change the nature of the confidence relationship. For instance, the possibility of a vote of no confidence in the German system still determines a permanent confidence relationship, even though the Bundestag can express its lack of 
confidence in the Federal Chancellor 'only by electing a successor by the vote of a majority of its members' (art. 67, German Basic Law).

2) The confidence relationship is not a merely-formal aspect, but it includes both legal elements and political factors. It is a dynamic criterion, which derives from the legal rules on inter-institutional relations, but still can be altered by the political context. The rules that determine the way in which the executive-legislature relationship works are usually described by legal sources. Jennings $(1943,82)$ wrote that even the conventions that generated the British cabinet government 'assume the legal relations between king and Parliament', whereas they 'presuppose the law'. However, at the same time, those rules may be altered by how the political actors interpret the constitution and by their consequent behaviour. Even if the legal rules concerning the system of government constrain the possible behaviours of political actors (Luciani 2010, 566), they are nevertheless 'open' rules that may be 'qualified' by parties and integrated by the constitutional conventions that they create (Elia 1970, 640). In other words, political practice works as a 'vehicle' that brings party dynamics into the structure of the system of government (Staiano 2012, 13). The notion of confidence relationship takes into account this mechanism and allows us to analyse and classify these models accordingly, going beyond the mere legal-formal data.

Important cases of semi-presidentialism are valid examples of how this mechanism works. In the Austrian experience, the President never exerts the power of dismissal in practice, which is the strongest power that he or she has over the government (Müller 2003), and the presidential power of appointment is in reality 'driven' by the majorities in Parliament. Duverger $(1980,167)$ noted that the constitution of Austria is semi-presidential, while political practice in that country is parliamentary. By neutralizing the presidential powers of discretionary appointment and dismissal, the party dynamics have excluded the President from the confidence scheme, which consequently operates only between the legislature and the government: the result is a system that functions as if it were parliamentary. The inverse has happened in France. The French Constitution does not give great personal powers to the president (except the 'emergency' powers in art. 16), but most prerogatives are related to the role of an 'arbitrator'. In practice, except in case of cohabitation, much greater powers are exerted (Duverger 1980, 170); in particular, the discretionary dismissal of the Prime Minister, which is exactly what establishes the nature of the French confidence scheme. In short, if parliamentarism in Austria depends on political practice, the same can be said with regard to semi-presidentialism in France.

3) The concept of confidence takes into account that both the executive and the legislative branches may be composed of more than one body, and each body may participate in the confidence relationship differently. Semi-presidentialism, for example, is characterized by a 'dual' executive whose one of the two 'heads' (Sartori 1994) depends on the confidence of the other; while the peculiarities of the Australian and Japanese 'dual legislatures' have led an author to introduce the idea of 'chamber-independent government' (Ganghof 2014 and 2015). Verifying the type of confidence scheme between the executive and the legislature is a valid strategy. This approach simplifies the classification process, allowing us to describe how the different experiences work in practice, and sheds light on the essential structure of the general models. The following section defines the confidence relationship among the main European 
institutions by focusing on the Treaties and verifying if the actual political practice has altered the formal set of inter-institutional relations.

\section{The confidence relationship in the $\mathbf{E U}$ model}

As far as the EU institutions are concerned, the Treaties specify that the European Parliament and the Council exercise together 'legislative and budgetary functions' (art. 14, para. 1, TEU), within a bicameral legislative branch (Kreppel 2011, 173). There is also a 'dual' executive composed of the European Council and the Commission. The latter, which has been defined as a 'technical executive' (Fabbrini 2013, 1005), promotes the general interest of the Union, exerts coordinating, executive and management functions, and has the power to propose legislative acts (art. 17, TEU); the former, which for Kreppel $(2011,170)$ is the true 'political executive', 'shall provide the Union with the necessary impetus for its development and shall define the general political directions and priorities thereof' (art. 15, para. 1, TEU). In short, 'the Lisbon Treaty has set up a governmental structure organized around two distinct legislative chambers and two distinct executive institutions' (Fabbrini 2013, 1005).

The structure of the system of government of the European Union is defined by how the confidence scheme between the executive and the legislative branches works. The relevant norms are those concerning the appointment/election (initial confidence) and the political accountability (permanent confidence) of the two bodies of the executive.

As far as the European Council is concerned, it consists of the heads of state or government of the member states, together with its President and the President of the Commission (art. 15, para. 2, TEU). Its legitimacy derives from the democratic schemes that operate at national level, and its members are involved in the confidence relationships that exist within the national systems to which they belong. The President of the European Council has a confidence linkage with the European Council itself (according to art. 15, para. 5, TEU), and with the national governments.

As far as the Commission is concerned, the general rules regarding its appointment are described in art. 17, para. 7, TEU, which delineates three stages: 1) the European Council, taking into account the elections to the European Parliament and after having carried out appropriate consultations, proposes a candidate for President of the Commission to the European Parliament, which elects the candidate by a majority of its component members (if this required majority is not reached, the European Council proposes a new name within one month); 2) the Council, in agreement with the President-elect, adopts the list of the other members of the Commission, who are selected on the basis of the suggestions made by the member states; 3 ) the Commission is subject as a body to a vote of consent by the European Parliament, and, on the basis of this vote, it is appointed by the European Council with a qualified majority.

According to this procedure, the Commission derives both from the Parliament and from the European Council. On the one hand, the Parliament elects the candidate for the presidency and subjects the Commission as a body to a vote of consent, giving its initial confidence in two different stages; on the other hand, the European Council selects the candidate for the presidency and appoints the Commission, whose members are chosen on the basis of the names suggested by the national governments themselves. In brief, the Treaties link the 
Commission, at its formation stage, to the Parliament and to the European Council, delineating an initial two-fold confidence relationship.

In addition, the Commission requires also a permanent confidence from the EP. It is 'responsible' to the Parliament, which may vote on a motion of censure (art. 17, para. 8, TEU) and entail its resignation (see also art. 234, TFEU). The nature of the motion is controversial. Some argue that the European Parliament can censure the Commission only for moral misconducts, but not for political reasons (Fabbrini 2015, 578; Decker and Sonnicksen 2011, 175-176). Conversely, Maduro (2013, 137) notes that, although the Commission is 'completely independent', and its members 'shall neither seek nor take instructions from any Government or other institution, body, office or entity' (art. 17, para. 3, TEU), the independence 'must be interpreted as referring to independence from national governments and any other particular interests'. He continues that its accountability to the Parliament 'makes it clear that the Commission is no longer supposed to be an independent technocratic body, but a politically accountable one'. Generally speaking, the moral requirement does not seem consistent with the collective nature of the censure, while, from a legal perspective, the Treaties do not specify that the censure has to derive from a specific misconduct. It is true that the motion of censure 'is carried by a two-thirds majority of the votes cast, representing a majority of the component Members of the European Parliament' (art. 234, para. 2, TFEU); however, as explained above, formal factors (such as the type of majority required) might concern exclusively how the mechanism works, without affecting the 'no-confidence' nature of the motion. The confidence relationship is established with the institution (the Parliament), not with the majority party. In addition, the provision according to which the term of office of the new Commission expires 'on the date on which the term of office of the members of the Commission obliged to resign as a body would have expired' (art. 234, para. 2, TFEU) links the 'life' of the executive institution to the parliamentary elections. It is therefore possible to argue that the relationship between the EP and the Commission presents a confidence nature (in the sense that the latter is a permanent 'emanation' of the former, until the next elections). The Treaties delineate a two-fold initial confidence relationship that links the Commission both to the EP and to the European Council (by means of different majorities), and a specialmajority permanent confidence relationship between the Commission and the EP. The provisions concerning the High Representative of the Union for Foreign Affairs and Security Policy entail a slight divergence from this scheme. Indeed, the High Representative, which is also one of the Vice Presidents of the Commission, is appointed by the European Council (by a qualified majority, with the agreement of the President of the Commission) and confirmed by the EP's initial vote of consent; however, it is not only subject to the parliamentary motion of censure of the Commission as a body (for the duties that he carries out in the Commission), but it can be removed also by the European Council (art. 18, para. 1, TEU). In other words, one of the Vice Presidents of the Commission is subject to the European Council's permanent confidence as well.

It is worth pointing out that, while The Council (of Ministers) has no confidence linkage with the Commission, the national parliaments participate actively in these processes through the confidence schemes that connect them to the members of the European Council. In this sense, it is possible to argue that the European Council is the institution that brings the national political dynamics into the supranational level. Indeed, it is through the formal powers of this 
institution that national party politics end up affecting EU political decisions, such as the appointment of the Commission.

The complex confidence scheme that operates in the EU is shown in Figure 1.

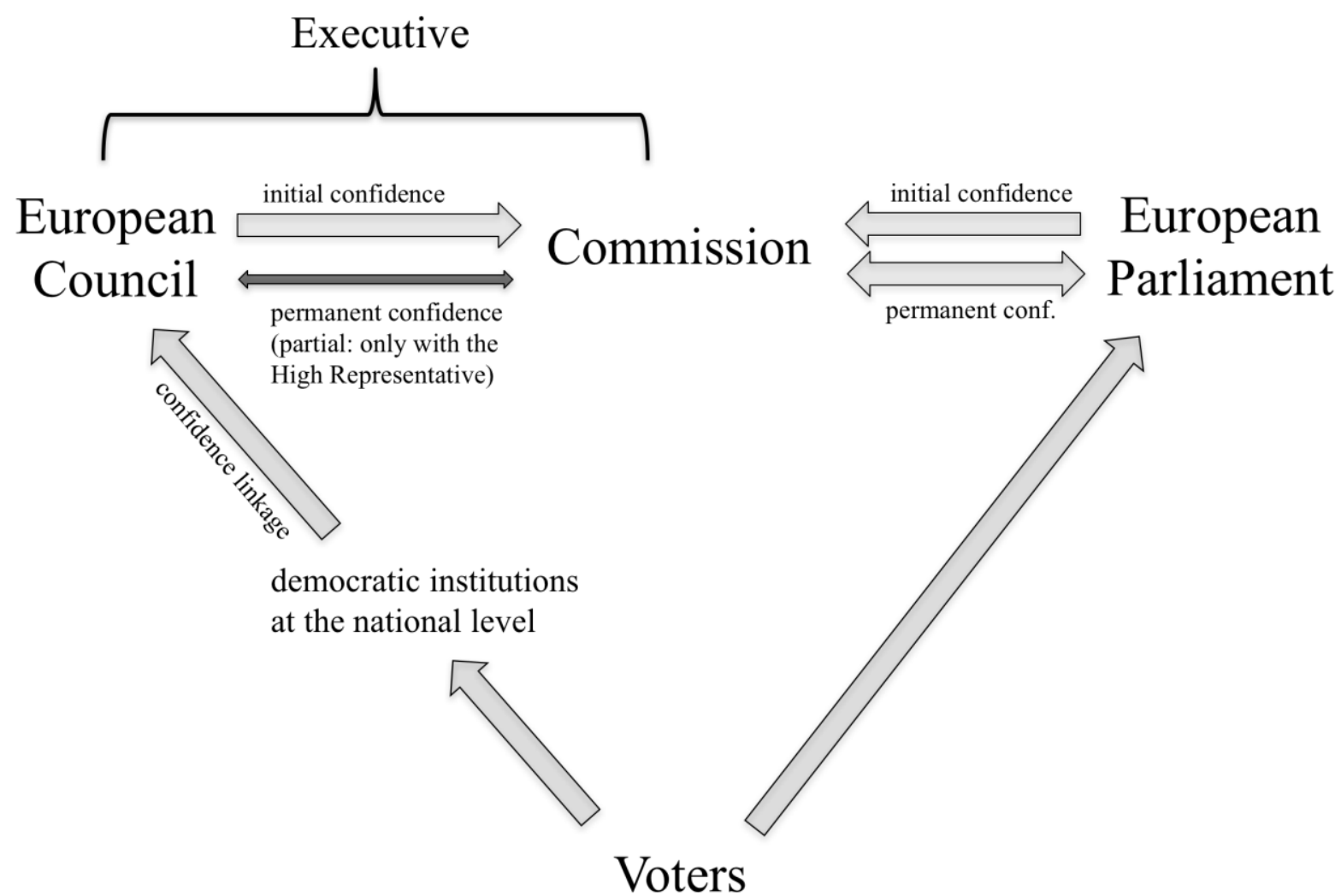

Figure 1: Confidence scheme in the EU

Similar formal rules, in different contexts, may lead to different solutions, and the behaviour of political actors is often an essential element (Rescigno 1989, 22). From this point of view, in the EU experience, the actual practice has not altered the formal scheme delineated by the Treaties.

As far as the two-fold initial confidence is concerned, it has been demonstrated that the member state governments (represented in the European Council) are fully involved in the appointment of the commissioners, choosing candidates that have preferences similar to their own (Wonka 2007). The recent 2014 elections have confirmed this tendency. After all, the Juncker Commission is the result of a 'complex set of negotiations aimed to identify, also, the new president of the EP (the socialist, Martin Shulz) between the main EP parties and the governmental leaders of the European Council' (Fabbrini 2015, 577). Despite the increase of parliamentary powers regarding the investiture of the Commission, and despite the fact that before the 2014 elections the main European parties have actually presented their Spitzenkandidaten for the presidency of the Commission, the political strength of the national governments in the Commission's appointment process is still relevant. Certainly, by imposing one of the Spitzenkandidaten 'the Parliament set an important precedent for the future which weakens the power of the European Council to select its own preferred 
candidates' (Hobolt 2014, 1537). However, that precedent does not seem able to transform the role of the European Council into a merely formal appointment (as it happens to the role of the head of state in parliamentary systems). Indeed, the 'game' still depends on the actual involvement of the national leaders in the choice of the commissioners (Decker 2014, 320).

In addition, the EP has used its internal rule-making autonomy to create a procedure of hearings (see rule 118, Rules of Procedure of the European Parliament) that allows it to exert control over the national government's nominees as commissioners (Moury 2007), reinforcing its political role during the formation stage of the Commission. In 2004, it forced the President-elect José Manuel Barroso to replace some of the nominees as commissioners, by threatening to reject the whole Commission (see Corbett et al. 2005, 262); in October 2014, despite the support received by Juncker, Alenka Bratušek had to withdraw her candidacy as commissioner after parliamentary rejection (McGowan and Phinnemore 2015, 38). Although the European Parliament has not been able to impose the nomination of commissioners yet, it has nevertheless proved itself able to exert control over the names proposed. In this sense, if a candidate is approved, it means that he or she has received parliamentary trust (which is formalised in the collective vote of consent).

It seems accurate to conclude that the current practice does not reject the idea of a two-fold initial confidence. Both the European Council and the EP contribute to determine the composition of the Commission, although so far the former has been the 'strongest' institution, while the latter has had a merely 'confirmatory' role (Decker 2014, 321).

As far as the Commission's formal accountability to the European Parliament is concerned, no motion of censured has ever been approved, and only a few have been presented so far (the most recent, presented in May 2016, but soon withdrawn, concerned the Commission's failure to publish scientific criteria for defining endocrine disruptors). However, the Commission's political linkage to the EP has not been questioned by a conflicting practice. The crisis of the Santer Commission in 1999, which had to resign to avoid that the EP voted a motion of censure (see Corbett et al. 2005, 272f.), suggests that, in the end, the 'life' of the Commission is somehow linked to the political dynamics within the EP. Indeed, 'a key factor' in the decision to resign was the shift of position of the socialist group, and 'although no final censure vote was held, in practice the Santer Commission was censured by the European Parliament' (Hix et al. 2007, 191). It is not unusual for executives to resign before the Parliament votes a motion of no confidence, when they no longer enjoy parliamentary support. Neither the fact that no censure has ever been approved, nor the formal requirements of the procedure (such as the type of majority required) exclude the 'no-confidence' nature of the motion.

It is therefore possible to argue that the confidence scheme established by the Treaties has not been altered by a conflicting practice. As anticipated, this scheme is based on a two-fold initial confidence relationship (the Commission derives both from the EP and from the European Council) and on a complex permanent confidence according to which a special majority within the EP can vote down the Commission as a whole, while the European Council can remove the High Representative (by qualified-majority). 


\section{Comparing the EU model to the traditional regime types}

Having described the EU model, it is now possible to compare it with the traditional regime types. The aim is to verify if it belongs to any of the general categories, or if it rather represents a distinct model.

a) Is the EU comparable to presidentialism?

If presidentialism is based on the idea of 'constitutional separation of origin and survival' (Samuels and Shugart 2010, 15; Shugart and Carey 1992, 19), it can be argued that presidential systems are characterized by the absence of any confidence relationship. On the one hand, at the election stage, the chief executive receives its legitimacy by popular vote, not by the legislature; on the other hand, the latter cannot affect the permanence in office of the former with a vote of no confidence. As pointed out above, impeachment procedures do not alter the nature of this type of relationship, since impeachment is not a tool that can be used in case of a lack of political support, but a judicial mechanism connected to unlawful behaviours. The EU is far from being comparable to a system based on the absence of any specific confidence procedure that involves the legislature in the origin and survival of the executive. Indeed, one of the two branches of its executive (the Commission) depends on the confidence of two other institutions, both during its formation stage and for as long as it remains in office.

b) Is the EU a parliamentary system?

Parliamentarism is characterized by a scheme of inter-institutional relations that may be synthesized as a 'political fusion and institutional interdependence between the legislature and the executive' (Fabbrini 2015, 572). This interdependence develops from a confidence relationship that is both initial and permanent: it is initial because the executive derives from the legislative, whereas it does not have an autonomous 'electoral origin' (Colomer and Negretto 2005, 73); it is permanent because the former must have the support of the latter in order to remain in office. In other words, in parliamentary experiences, the government is a 'permanent emanation' (Elia 1970, 642) of the legislative branch, since it is both 'chosen by, and responsible to' it (Gerring et al. 2005, 571). In parliamentarism, however, the confidence relationship exists exclusively between the legislature and the cabinet. In the EU, the 'dual' nature of the executive entails a much more complex relationship scheme. The European Council (i.e. one of the two bodies of the executive) plays an important political (not only formal) role in the Commission's formation process, and for this reason the EU is not a parliamentary system of government.

c) Is the EU comparable to semi-presidential regimes?

In semi-presidentialism, the confidence relationship concerns more than two institutions. In reality, the confidence scheme operates between the executive and the legislature, but as Sartori (1994) explained, the former has 'two heads', i.e. the President and the Prime Minister, and both of them are involved. A President (normally elected by popular vote) 'shares' the executive power with a Prime Minister that needs the Parliament's support to remain in office; and that the Prime Minister may be 'caught between the president and the parliament' (Siaroff 2003, 292), being appointed and dismissed at the discretion of the President. This system has a certain degree of flexibility. In particular, the prevailing of the 'two heads' of the executive 
may change according to the majority in Parliament (Sartori 1994). When the President is the leader of the majority political force, he or she exerts more powers than the Prime Minister. However, in case of different partisan majorities in the Parliament and the presidency, the President still has to appoint a Prime Minister that enjoys the support of the legislative assembly, and this situation entails that the Prime Minister prevails over the President that belongs to a different political wing (cohabitation). In order to avoid this political circumstance, in 2000 the duration of the presidential term of office in France has been reduced from seven to five years, matching the term of office of the National Assembly.

Semi-presidentialism is based on a peculiar relationship scheme, which is characterized by a 'two-fold confidence' (Duverger 1980, 178). More precisely, in semi-presidentialism the Prime Minister needs an initial and permanent two-fold confidence, since he or she is accountable to Parliament but depends also on the 'confidence of the president' (Samuels and Shugart 2010, 30), both at the appointment stage and for as long as he or she remains in office (except in case of cohabitation). This type of confidence relationship is similar to the one that characterizes the EU model. There is, however, a significant difference: in the EU, only the initial confidence is two-fold, while the permanent confidence links the Commission exclusively to the EP (only the High Representative can be voted down by the European Council). In addition, the EU lacks a popularly elected head of state, which is one of the main aspects of semi-presidential systems.

d) Is the EU comparable to the Swiss directorial system?

In the unique Swiss model, the members of the Federal Council are elected by the Federal Assembly for a four-year fixed term of office (art. 175, Swiss Constitution). That system is based on a separation of power structure with institutional bodies that cannot affect each other from the perspective of their permanence in office. However, the composition of the Federal Council still depends on the political forces in Parliament, and its members receive a formal parliamentary support in the moment of their investiture. As it has been pointed out (Klöti 2001, 22; Kriesi 2001, 59), this peculiar regime is neither presidential nor parliamentary. On the one hand, the executive has a fixed term of office, and a vote of no-confidence is not possible; on the other hand, it is chosen by the legislature, not by popular vote. Luciani (2010, 548) has conceptualized the investiture of the Federal Council as being similar to a parliamentary vote of confidence, explaining that, in this case, the relationship is merely initial, since it can be expressed only at the executive's formation stage and only with one act (the election of the members). In Switzerland the confidence relationship is initial, but not permanent: the legislature chooses the executive, but it is not able to affect its permanence in office, since once elected the latter cannot be 'brought down' (Dardanelli 2005, 124). In the $\mathrm{EU}$, the Commission is responsible to the EP, and can be removed before the end of its term. Therefore, the two models are not comparable.

e) Is the EU comparable to the models based on the principle simul stabunt simul cadent?

Parliamentarism is not the only possible solution when the constitutional framework delineates the government's permanent political accountability to the legislature. In this regard, it is worth mentioning the unique model that existed in Israel between 1992 and 2001. In that system, the Prime Minister was elected in national general elections, 'conducted on a 
direct, equal, and secret basis' (art. 3b, Basic Law: The Government, 1992), but was also subject (along with the Cabinet) to parliamentary confidence. The distinctive feature was exactly the peculiar nature of the executive-legislature relations (see Hazan 1996, 33). The Prime Minister needed the permanent confidence of the legislature, but he or she was legitimized by popular elections. The coexistence between popular legitimacy and parliamentary control entailed that a vote of no confidence in the Prime Minister was considered as 'a Knesset decision to disperse prior to the completion of its period of service' (art. 19b). A similar system is currently adopted in Italy at the regional level.

In these cases, the confidence relationship is characterized by the absence of an initial trust from Parliament and by the formula simul stabunt simul cadent (together they will stay, together they will fall): a motion of no confidence against the head of the government entails necessarily the dissolution of the legislature. This type of relationship is not present within the EU, where there is an initial confidence relationship (two-fold), and, therefore, no direct election of the President of the Commission (as well as no dissolution of the legislature).

f) Is the EU model a form of 'chamber-independent government'?

Ganghof (2014 and 2015, 825) has introduced the notion of 'chamber-independent government' to describe those systems in which, despite the presence of two legislative chambers equally powerful and equally legitimate, only one of them can dismiss the executive. In these cases, the confidence relationship is 'asymmetric' within a legislative branch characterized by two symmetric chambers. The 'clearest case' of this form of government is the Australian state of New South Wales. The EU model presents a similar feature: the EP and the Council (of Ministers) share legislative powers and they both represent the citizens (although the latter only indirectly, though the democratic schemes at the national level), but only the former has a confidence linkage with the Commission. Compared to the archetype described by Ganghof, however, the confidence scheme in the EU is much more complex, since it also involves the European Council at different levels.

\section{Concluding remarks}

This paper starts from the premise that, in order to simplify the classification of regime types, we should focus on the 'structure' of the general archetypes, particularly on the scheme of inter-institutional relations between the executive and legislative branches. The term 'confidence relationship' has been applied, because that 'structure' derives from the combination of two different types of trust: initial (in the formation stage of the cabinet) and permanent (for as long as the executive remains in office). In adopting this concept, six general models of system of government have been identified: a) absence of any specific confidence procedure that involves the legislature in the origin and survival of the executive (i.e. presidentialism); b) initial and permanent confidence (i.e. parliamentarism); c) initial and permanent two-fold confidence, both from the legislature and from one of the branches of a 'dual' executive (i.e. semi-presidentialism); d) initial but not permanent confidence (Switzerland); e) permanent but not initial confidence and principle simul stabunt simul cadent (Israel 1992-2001); f) 'asymmetric' confidence relationship, when only one of two equally powerful chambers is involved (i.e. 'chamber-independent' government). 
The EU does not belong to any of these categories. Indeed, it represents a specific distinct model. The EU is based on a two-fold initial confidence relationship that links the Commission both to the EP and to the European Council (and thus to the national governments), and on a complex permanent confidence relationship according to which a special majority within the EP can vote down the Commission as a whole, while the European Council by qualified-majority can remove the High Representative (one of the Vice Presidents of the Commission).

The two-fold initial confidence of the EU model resembles semi-presidentialism, but it is much more complex. Firstly, it is based on a mechanism that concerns not only the President of the Commission, but all its members. In addition, it is multi-level in nature, since the appointment procedure, involving the European Council, ends up including national political dynamics. In short, the initial confidence of the EU model is the result of three different dimensions: confidence schemes at the national level, balance among national governments within the European Council, and balance between the latter and the EP. If the Commission needs the permanent confidence of the EP, the rules on the removal of the High Representative entail a partial permanent linkage with the European Council.

In conclusion, the EU model represents a unique regime type in which both vertical and horizontal confidence schemes converge in the European Council, while the 'life' of the Commission is linked to the European Parliament (and its elections). For this reason, this 'new' system could be classified as a 'Council-based' form of government with parliamentary features. In other words, the European Council plays a relevant role in the confidence scheme, also connecting the national and supranational levels of government, while the EP exerts political control.

Researchers will certainly continue to study the development of this peculiar system, and the idea of a confidence relationship is a valid and useful tool, as it sheds light on how actual practice might alter the 'structure' (and thus the nature) of the model. In this sense, the confidence concept shows why the EU today does not belong to any of the traditional categories. It might also help to explain to what extent it could shift towards full parliamentarism (if the powers of the European Council became merely formal) or, conversely, towards a complete separation of powers system (if the political will of the European Council prevailed completely over the EP's prerogatives). 


\section{References}

Bobbio, N. 1995. Stato, governo, società. Frammenti di un dizionario politico. Torino: Einaudi.

Bogdanor, V. 1986. The Future of the European Community: Two Models of Democracy. Government and Opposition 21, no. 2: 161-76.

Cheibub, J.A., Z. Elkins, and T. Ginsburg. 2014. Beyond Presidentialism and Parliamentarism. British Journal of Political Science 44, no. 3: 515-544.

Colomer, J.M., and G.L. Negretto. 2005. Can Presidentialism Work Like Parliamentarism? Government and Opposition 40, no. 1: 60-89.

Corbett, R., F. Jacobs, and M. Shackleton. 2005. The European Parliament (6th ed.). London: John Harper Publishing.

Dann, P. 2003. European Parliament and Executive Federalism: Approaching a Parliament in a Semi-Parliamentary Democracy. European Law Journal 9, no. 5: 549-74.

Dardanelli, P. 2005. The Parliamentary and Executive Elections in Switzerland, 2003. Electoral Studies 24, no. 1: 123-129.

Decker, F., and J. Sonnicksen. 2011. An Alternative Approach to European Union Democratization: Re-Examining the Direct Election of the Commission President. Government and Opposition 46, no. 2: 168-191.

Decker, F. 2014. The Pitfalls of Parliamentarisation: Why the Procedure of Appointing the European Commission Should Be Changed. European View 13, no. 2: 319-326.

Duverger, M. 1980. A New Political System Model: Semi-Presidential Government. European Journal of Political Research 8, no. 2: 165-187.

Elgie, R. 1998. The Classification of Democratic Regime Types: Conceptual Ambiguity and Contestable Assumptions. European Journal of Political Research 33, no. 2: 219-238.

Elgie, R. 2007. What Is Semi-Presidentialism and Where Is It Found? In Semi-Presidentialism Outside Europe: A Comparative Study, eds. R. Elgie and S. Moestrup, 1-13. London and New York: Routledge.

Elia, L. 1970. Governo (forme di). In Enciclopedia del diritto (Vol. XIX). Milano: Giuffrè.

Fabbrini, S. 2005. Madison in Brussels: The EU and the US as Compound Democracies. European Political Science 4, no. 2: 188-98.

Fabbrini, S. 2013. Intergovernmentalism and Its Limits: Assessing the European Union's Answer to the Euro Crisis. Comparative Political Studies 46, no. 9: 1003-1029.

Fabbrini, S. 2015. The European Union and the Puzzle of Parliamentary Government. Journal 
of European Integration 37, no. 5: 571-586.

Ganghof, S. 2014. Bicameralism as a Form of Government (Or: Why Australia and Japan Do Not Have a Parliamentary System). Parliamentary Affairs 67, no. 3: 647-663.

Ganghof, S. 2015. Is the 'Constitution of Equality' Parliamentary, Presidential or Hybrid? Political Studies 63, no. 4: 814-829.

Gerring, J., S.C. Thacker, and C. Moreno. 2005. Centripetal Democratic Governance: A Theory and Global Inquiry. American Political Science Review 99, no. 4: 567-581.

Hazan, R.Y. 1996. Presidential Parliamentarism: Direct Popular Election of the Prime Minister, Israel's New Electoral and Political System. Electoral Studies 15, no. 1: 21-37.

Hix, S., A.G. Noury, and G. Roland. 2007. Democratic Politics in the European Parliament. Cambridge: University Press.

Hix, S. 2008. What's Wrong with the European Union and How to Fix It. Cambridge: Polity Press.

Hobolt, S.B. 2014. A Vote for the President? The Role of Spitzenkandidaten in the 2014 European Parliament Elections. Journal of European Public Policy 21, no. 10: 1528-1540.

Huber, J.D. 1996. The Vote of Confidence in Parliamentary Democracies. American Political Sciences Review 90, no. 2: 269-282.

Jennings, I. 1943. The Law and the Constitution (3rd ed.). London: University of London Press.

Klöti, U. 2001. Consensual Government in a Heterogeneous Polity. West European Politics 24, no. 2: 19-34.

Kreppel, A. 2011. Looking 'Up', 'Down' and 'Sideways': Understanding EU Institutions in Context. West European Politics 34, no. 1: 167-179.

Kriesi, H. 2001. The Federal Parliament: The Limits of Institutional Reform. West European Politics 24, no. 2: 59-76.

Lijphart, A. 1984. Democracies: Patterns of Majoritarian and Consensus Government in Twenty-One Countries. New Haven: Yale University Press.

Lijphart, A. 1999. Patterns of Democracy: Government Forms and Performance in Thirty-six Countries. New Haven: Yale University Press.

Linz, J.J. 1990. The Perils of Presidentialism. Journal of Democracy 1, no. 1: 51-69.

Luciani, M. 2010. Governo (forme di). In Enciclopedia del diritto (Annali III). Milano: Giuffrè.

Maduro, M.P. 2013. A New Governance for the European Union and the Euro: Democracy 
and Justice. Yearbook of Polish European Studies, no. 16: 111-140.

McGowan, L., and D. Phinnemore. 2015. A Dictionary of the European Union. London and New York: Routledge.

Moury, C. 2007. Explaining the European Parliament's Right to Appoint and Invest the Commission. West European Politics 30, no. 2: 367-391.

Müller, W.C. 2003. Austria: Imperfect Parliamentarism but Fully-Fledged Party Democracy. In Delegation and Accountability in Parliamentary Democracies, eds. K. Strøm, W. C. Müller and T. Bergman, 221-252. Oxford: Oxford University Press.

Pizzorusso, A. 1998. Sistemi giuridici comparati. Milano: Giuffrè.

Praino, D. 2014. La definizione e il funzionamento della forma di governo nel contesto partitico. In Nella rete dei partiti. Trasformazione politica, forma di governo, network analysis, ed. S. Staiano, 3-32. Napoli: Jovene.

Rescigno, G.U. 1989. Forme di Stato e forme di governo. In Enciclopedia giuridica (Vol. XIV). Roma: Treccani.

Samuels, D.J., and M.S. Shugart. 2010. Presidents, Parties, and Prime Ministers. How the Separation of Powers Affects Party Organization and Behavior. Cambridge: University Press.

Sartori, G. 1994. Comparative Constitutional Engineering. An Inquiry into Structures, Incentives, and Outcomes. London: Macmillan.

Shugart, M.S., and J.M. Carey. 1992. Presidents and Assemblies. Constitutional Design and Electoral Dynamics. New York: Cambridge University Press.

Siaroff, A. 2003. Comparative Presidencies: The Inadequacy of the Presidential, SemiPresidential and Parliamentary Distinction. European Journal of Political Research 42, no. 3: 287-312.

Staiano, S. 2012. Prolegomeni minimi a una ricerca forse necessaria su forma di governo e sistema dei partiti. Federalismi.it, no. 3: 1-21.

Verney, D.V. 1959. The Analysis of Political Systems. Glencoe: The Free Press.

Weiler, J.H.H. 2013. European Parliament Elections 2014: Europe's Fateful Choices. The European Journal of International Law 24, no. 3: 747-753.

Wonka, A. 2007. Technocratic and Independent? The Appointment of European Commissioners and Its Policy Implications. Journal of European Public Policy 14, no. 2: 169-89. 